\title{
Phytophagous insects and predatory arthropods in soybean and zinnia
}

\author{
ERISE ANGGRAINI ${ }^{1,2,4, \bullet}$, WIDA NUR ANISA ${ }^{1}$, SITI HERLINDA ${ }^{1,4}$, CHANDRA IRSAN $^{1,4}$, SUPARMAN $^{3}$ \\ SUPARMAN ${ }^{1}$, SUWANDI SUWANDI ${ }^{1,4}$, MUHAMMAD UMAR HARUN ${ }^{3}$, BAMBANG GUNAWAN ${ }^{1}$ \\ ${ }^{1}$ Department of Plant Pests and Diseases, Faculty of Agriculture, Universitas Sriwijaya. Jl. Raya Palembang-Prabumulih Km 32, Indralaya, Ogan Ilir \\ 30662, South Sumatra, Indonesia. Tel.: +62-711-580663, Fax.: +62-711-580276. ^email: erise.anggraini@unsri.ac.id \\ ${ }^{2}$ Study Program of Agroecotechnology, Faculty of Agriculture, Universitas Sriwijaya. Jl. Raya Palembang-Prabumulih Km 32, Indralaya, Ogan Ilir \\ 30662, South Sumatra, Indonesia \\ ${ }^{3}$ Department of Agronomy, Faculty of Agriculture, Universitas Sriwijaya. Jl. Raya Palembang-Prabumulih Km 32, Indralaya, Ogan Ilir 30662, South \\ Sumatra, Indonesia \\ ${ }^{4}$ Research Center for Sub-optimal Lands, Universitas Sriwijaya. Jl. Padang Selasa No.524,Palembang 30139, South Sumatra, Indonesia
}

Manuscript received: 10 June 2020. Revision accepted: 21 February 2021.

\begin{abstract}
Anggraini E, Anisa WN, Herlinda S, Irsan C, Suparman S, Suwandi S, Harun MU, Gunawan B. 2021. Phytophagous insects and predatory arthropods in soybean and zinnia. Biodiversitas 22: 1405-1414. In Indonesia, soybean is the third most important commodity after rice and corn. Cultivation technique such as planting hedgerows was expected to attract and retain natural enemies of pest predators. This study was conducted to determine the phytophagous insects and predatory arthropods species in soybean (Glycine max L.) and zinnia (Zinnia sp., hybrids) plants as refugia. This study utilized three methods i.e., visual observation, pitfall trap, net-trap in both soybean and zinnia planting areas. All collected insects were carried to the laboratory for observation and identification using insect determination key book. Insect identification was based on their morphological characteristics. The results study showed that phytophagous and predatory arthropods were found in both soybean and zinnia plantations in Agro-Techno Center (ATC), Sriwijaya University, Indonesia. There were 11 species of phytophagous and 5 species of entomophagous insects identified at soybean cultivation. Meanwhile, 5 species of phytophagous and 9 species of predatory arthropods including five spider species found, namely Pardosa distincta, Oxyopes javanus, Lycosa pseudomonas, Pardosa sp. and Drapetisca socialis at zinnia cultivation area. However, chi-square analysis (at alpha 0.05), confirmed that there was no significant difference between predatory arthropods in soybean and Zinnia the results indicate that soybean is might be suitable to be planted as refugia for predatory arthropods.
\end{abstract}

Keywords: Pedatory arthropods, refugia, soybean, Zinnia

\section{INTRODUCTION}

Soybean (Glycine max L) is an affordable and highly nutritious food commodity as source of protein, low cholesterol, and an important food commodity after rice and maize (Hasan et al. 2015). Fresh soybeans are needed in food industry and soybean meals are needed for the feed industry. The inability to supply domestic needs has caused continuous escalation of soybean imports. The presence of various pests had been obstacle to increase soybean production. Pests can easily attack soybean from the early growth stage until harvest.

Farmers in Indonesia generally use synthetic pesticides for managing agricultural land. The application of synthetic pesticides might have negative impacts, such as accumulation in yields, pest resistance, natural enemies' reduction, and the repeated use of persistent and nonbiodegradable pesticides, which has polluted various water, air, and soil components ecosystem (Gill and Garg 2014). Various efforts of more environmentally friendly Integrated Pest Management (IPM) have been carried out. Integrated Pest Management (IPM) is a decision-based process involving coordinated use of multiple strategies for optimizing the control of all class pests (insects, pathogens, weeds, vertebrates) in an ecologically and economically sound manner (Prokopy 2003). One of the efforts is by an intensive ecosystem-based control, namely ecological engineering.

Ecological engineering is the design of a sustainable system that is caring and consistent with the use of ecological principles that incorporate human activities with the natural environment for both side benefits (Kangas 2003). Ecological engineering uses cultural methods to suppress insect pests in which crop cultivation also provides the niches for natural enemies such as arthropods predators, and parasitoids. Natural enemies in a balanced nature always manage to control the pest population remains under economic level. Therefore, allowing natural enemies to work means reducing the use of pesticides. Conservation for natural enemies involves manipulation of environment to enhance the survival, fecundity, longevity, and behavior of natural enemies to enhance their effectiveness (Landis et al. 2000).

Pest control by planting edge or trap crops can encourage the stability of ecosystem for suppressing pest population to be in equilibrium. Selected edge crop types must have dual functions, besides being a barrier for pests to attack the main crop and temporary shelter and pollen providers for alternative predatory foods, if the main prey population is low or absent in the staple crop. Planting of flowering plants as refugia is a strategy for natural enemies conservation in biological control because the most 
important and widely exploited mechanism by which predators and parasitoids are supported by flowering plants in the provision of food sources, such as nectar and pollen (Wäckers and Van Rijn 2012). Refugia can increase the chances of environmental natural enemies in controlling pests in rice (Allifah et al. 2013).

Refugia is plant (both crops and weeds) that grows around cultivated crops, which one of the benefits is as a microhabitat for natural enemies (both predators and parasitoids). The preservation of natural enemies is created properly (Landis et al. 2000). Natural enemies are interested in the diversity of refugia plants as they play a role in habitat protection. To the beneficial role of natural enemy insects to help control pests, it is necessary to have efforts to conserve natural enemies by planting refugia plants along with the main crop.

Some plants had been known as refugia such as zinnia (Zinnia sp.), tagetes (Tagetes erecta), wild turnip (Rorippa indica), wild peanuts (Arachis pintoi), basil, clay, sunflower (Helianthus annuus), Cosmo caudatus, Sesamum indicum, vegetables (Cucumis sativus, Vigna sinensis, Luffa acutangula, and Momordica charantia) (Karenina et al. 2019). According to Karenina et al. (2019), the highest abundance of arthropods predators that inhabit non-crop plants are found in Zinnia sp. and Momordica charantia. Therefore, zinnia was used as a refugia in this study. In this study, refugia of zinnia flower plants (Zinnia sp., hybrids) were planted surrounding the soybean to determine the phytophagous and natural enemies associated with zinnia flowers as refugia and soybean.

\section{MATERIALS AND METHODS}

This study was conducted at Agro-Techno Center (ATC), Sriwijaya University, Indralaya, South Sumatra, Indonesia (decimal degrees of coordinate-3.2226567, 104.6463887). The area was $48 \times 12 \mathrm{~m}$. This area was processed using agricultural tools such as tractors and hoes then is divided into 9 beds of $12 \mathrm{~m}$, the distance between the beds and refugia were 2 meters. The spacing between soybeans was $20 \times 30 \mathrm{~cm}$.

Soybeans were fertilized once at the afternoon of planting day using cow manure as basal fertilizer. Each bed was supplied with $10 \mathrm{~kg}$ of fertilizer by spreading and trimming above the soil surface. Soybean variety was Deja 1 (Water resistant) from Indonesian Legumes and Tuber Crops Research Institute. Deja 1 variety used as the study was conducted at rainy seasons in November 2019-January 2020 with temperatures of $26.1-33.2^{\circ} \mathrm{C}$ and humidity of 82 $94 \%$. The spacing of soybean was $20 \times 30 \mathrm{~cm}$. The refugia seeds were taken and sprinkled on the ground. The space of zinnia flower with soybean was $0.5 \mathrm{~m}$ in which zinnia plants were planted four weeks earlier than soybean. Watering was done twice a day in the morning and evening for both soybean and refugia areas.

\section{Observation}

All of the observations (pitfall traps, net trap and visual observations) following Anggraini et al. (2020). Pitfall traps used to catch insects on the surface of the ground from four weeks after planting until harvest (total of 8 weeks observation). The installation of this trap was done in the evening and observed for 24 hours after installation. The trap was made by digging the soil as deep as $15 \mathrm{~cm}$ and $8 \mathrm{~cm}$ in diameter and then place plastic glass into the ground that was parallel to the surface of the soil. Previously, the plastic cup was filled with water mixed with $3 \mathrm{ml}$ of $90 \%$ alcohol. The location of the pitfall trap installation was applied by using the zigzag method. Collected insects put into vial bottles filled with $90 \%$ alcohol. The collected insects were observed and identified under stereomicroscope in Entomology Laboratory of Plant Pest and Disease Department, Agriculture Faculty, Sriwijaya University, Indonesia. Identification of spiders referred to Barrion and Litsinger (1995) and identification of insects referred to Kalshoven and Van der Laan (1981). The net was the air swing net used to catch flying insects. The insect net used was $35 \mathrm{~cm}$ in diameter and $50 \mathrm{~cm}$ in length with stick stalk as long as $100 \mathrm{~cm}$. Swing nets are used to catch insects in leaves or canopy. Intake of the insect was done by backing up the sun to avoid the insect comes out of the net. The net swung with 2 double swings in each plot. Trapped insects were gently taken placed in a jar for identification at Entomology Laboratory, Sriwijaya University, Indonesia.

\section{Identification}

The trapped insects, either phytophagous insects or entomophagous placed in vial bottles filled with $90 \%$ ethanol and labeled to avoid mistaken during identification. The insects caught in the traps that are placed either phytophagy insects or predatory arthropods we put in vial bottles that were previously given $90 \%$ ethanol and then labeled so as not to be mistaken when wanting to identify. The obtained phytophagous and entomophagous insects were more clearly identified by observing at body parts using microscope. Then morphological characteristic was carefully observed. Number of trapped insects counted, identified with insect determination key book.

\section{Data analysis}

Data of insect species both phytophagous and predatory arthropods obtained were presented in tabular form. The measurement of species diversity used Shannon-diversity index, Barger-Parker dominance index and Pielou evenness index. Statistically significant differences between the number of individual insects on soybean and Zinnia were compared by using the homogeneity chi-square test under the $\mathrm{R}$ application ver. 3.62 (R Foundation for Statistical Computing).

The Shannon-Wiener index $\left(\mathrm{H}^{\prime}\right)$ was calculated following Magurran (1988) by using the formula: $\mathrm{H}^{\prime}=-\sum$ (pi $x \ln \left(\right.$ pi)), where $H^{\prime}$ is the Shannon-Wiener index, $\ln$ is the natural logarithm, $\mathrm{N}$ is the number of all individuals, ni is the number of individuals in a species, and pi is the proportional number of individuals in a species $(\mathrm{pi}=\mathrm{ni} / \mathrm{N})$. The dominance index was calculated by following Berger and Parker (1970) with the formula: $d=N_{\max } / \mathrm{N}$, where $\mathrm{N}_{\max }$ is the number of individuals in the most abundant species, while $\mathrm{N}$ is the total number of individuals in the 
sample. The following formula calculated the evenness index: $\mathrm{E}=\mathrm{H}^{\prime} / \mathrm{ln} \mathrm{S}$, where $\mathrm{H}^{\prime}$ is the Shannon-Wiener index and $\mathrm{S}$ is the number of species. The evenness index value ranges from 0 to 1 ; if the value is 0 , it indicates that the evenness level of plant species in the community is very uneven, whereas if the value is close to 1 , then almost all the species that exist have the same abundance (Magurran 1988).

\section{RESULTS AND DISCUSSION}

Phytophagous insects and predatory arthropods found in net trap and pitfall trap at soybean cultivation

Active insects found in net trap of soybean canopy were 12 species from 9 families: Formicidae, Coccinellidae, Tettigoniidae, Acrididae, Curculionidae, Noctuidae, Aleyrodidae, Cicadellidae, and Cicadidae. The order of insects namely: Orthoptera, Hymenoptera, Coleoptera, Lepidoptera, and Hemiptera.

Those insects were identified as phytophagous and entomophagous. There were eight species of phytophagous insects including Bemisia tabaci, Bothrogonia addita, Spodoptera litura, Tetrix subulata, Locusta migratoria, Empoasca sp., Hypomeces sp., and Penthicodes sp. (Figure 1).

In addition, there were four species of entomophagous insect found, namely Odontoponera denticulata, Solenopsis sp., Coccinella transversalis, Micraspis discolor (Figure 2). The most abundant phytophagous insect was armyworm (Spodoptera litura) of 64 individuals, while entomophagous insect was the cocci beetle (Coccinella transversalis) of 61 respectively.

The number of active insects in the soil collected from pitfall traps in soybean cultivation area was less than those collected from net trap. The collected insects belong to 6 families including Gryllidae, Tettigoniidae, Formicidae, Tenebrionidae, Cicindellidae, and Cydnidae. There were seven species identified including four phytophagous insects and three entomophagous insects. Phytophagous insects were Gryllus sp., Tetrix subulata, Tenebrio molitor, and Cydnus aterrimus (Figure 3). While entomophagous insects were Odontoponera denticulata, Solenopsis sp., and Lophyra intermedia (Figure 4). Entomophagous insect known as black ants (Odontoponera sp.) was the most abundant as 63 individuals. Phytophagous insects which act as pests, namely Tetrix subulata was the most found of 68 individuals.

\section{Phytophagous insects and predatory arthropods found in net trap and pitfall trap at zinnia cultivation}

In a plant canopy in zinnia, nine species from 3 families of active insects were found in the net trap of soybean. The order of collected insects was Orthoptera, Coleoptera, and Araneae. Phytophagous insects collected were three species: Acraea violae (syn. Acraea terpsicore), Locusta migratoria, and Acrida cinerea (Figure 5). Butterflies (Acraea violae) were the most found in a total of 24 individuals. Predatory arthropods were six species, including Coccinela transversalis, Pardosa distincta, Oxyopes javanus, Lycosa pseudomonas, Pardosa sp., and Drapetisca socialis (Figure 6). Cocci beetle (Coccinella transversalis) was the most abundant predator of 40 individuals.

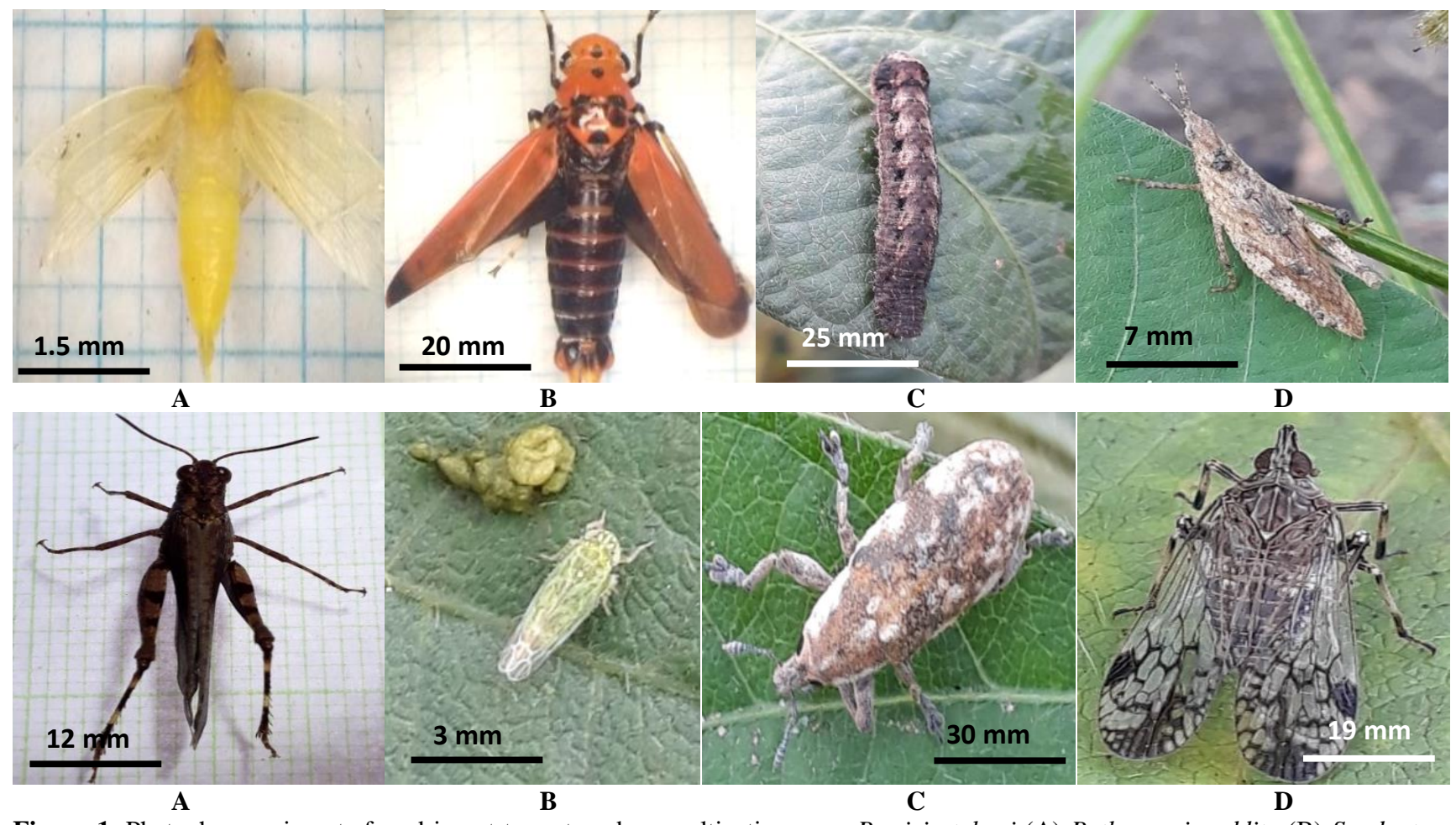

Figure 1. Phytophagous insects found in net trap at soybean cultivation area: Bemisia tabaci (A) Bothrogonia addita (B) Spodoptera litura (C) Tetrix subulata (D) Locusta migratoria (E) Empoasca sp. (F) Hypomeces sp. (G) Penthicodes sp. (H) 


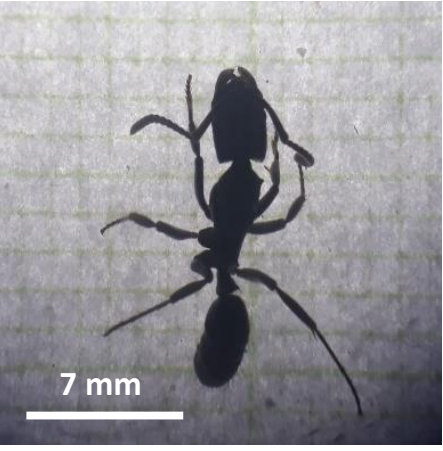

A

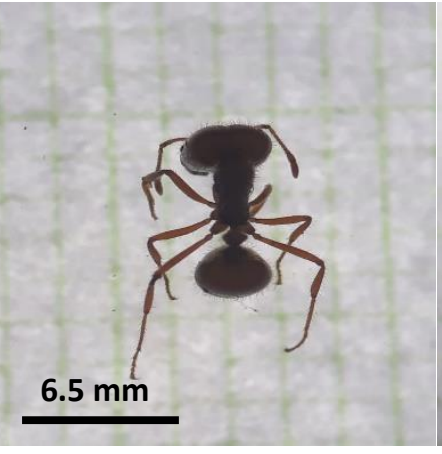

B

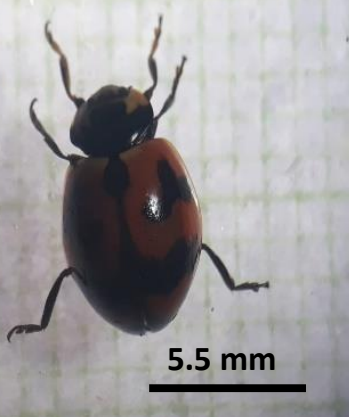

C

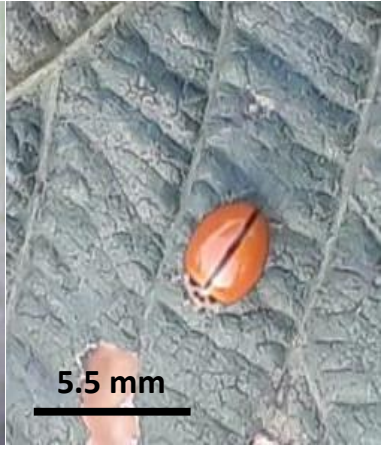

D

Figure 2. Entomophagous insects found in net trap at soybean cultivation area: Odontoponera denticulata (A), Solenopsis sp. (B), Coccinella transversalis (C), Micraspis discolor (D)

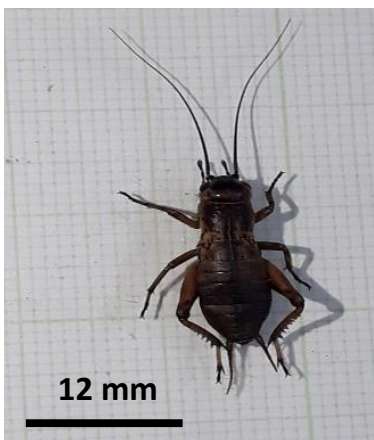

A

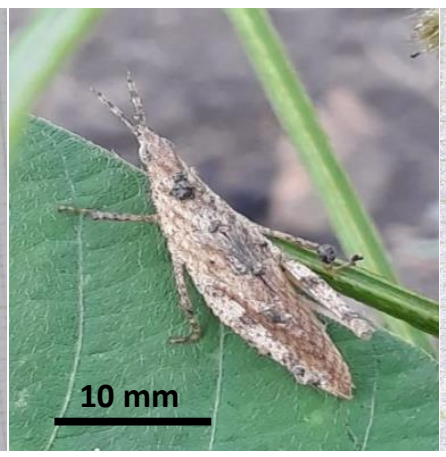

B

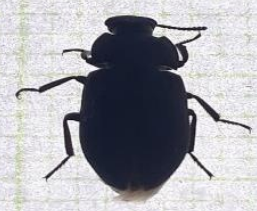

$9 \mathrm{~mm}$ C

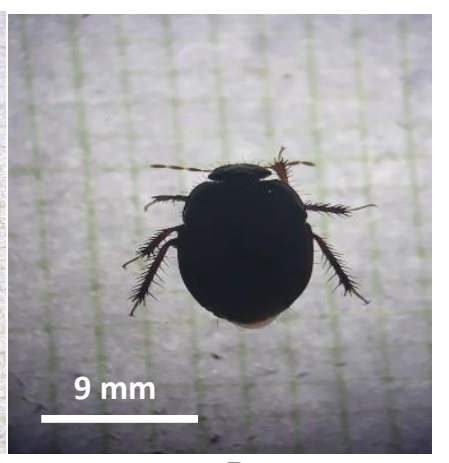

D

Figure 3. Phytophagous insects found in pit-fall trap at soybean cultivation area: Gryllus sp. (A), Tetrix subulata (B), Tenebrio molitor (C), Cydnus aterrimus (D)

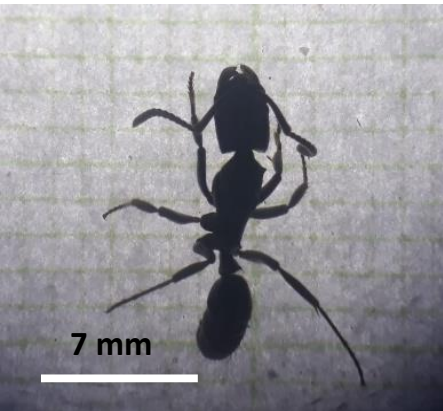

A

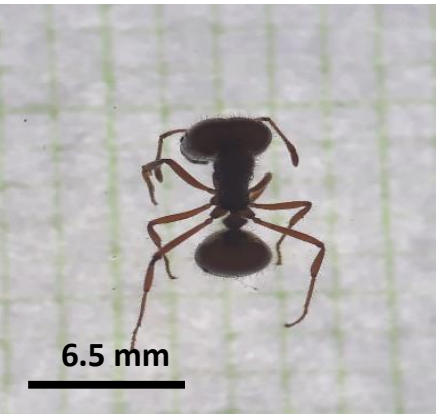

B

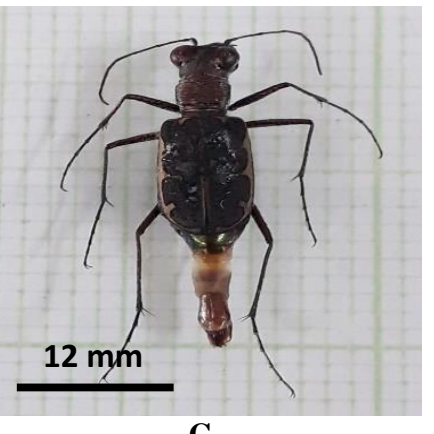

C

Figure 4. Entomophagous insects found in pit-fall trap at soybean cultivation area: Odontoponera denticulata (A), Solenopsis sp. (B), Lophyra intermedia. (C)

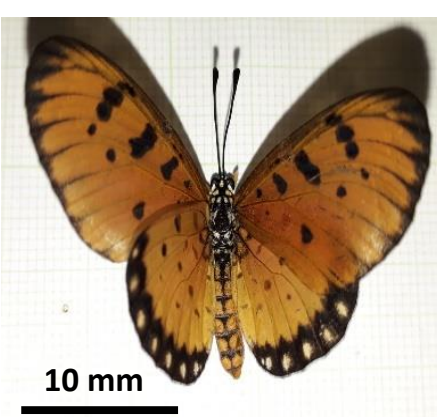

A

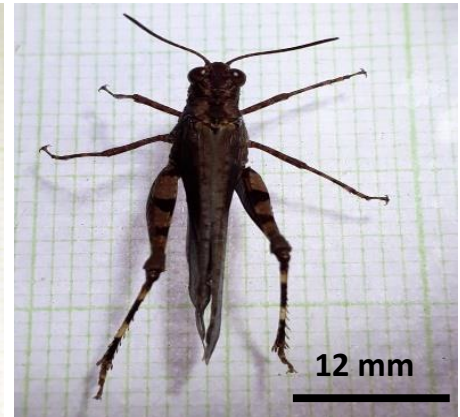

B

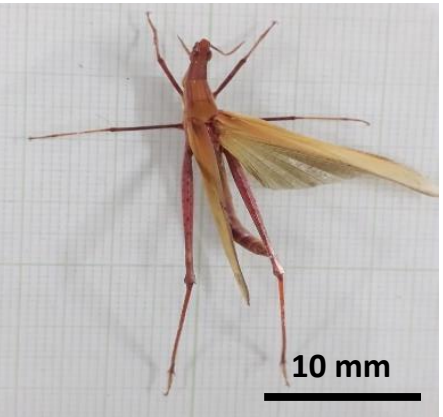

$\mathrm{C}$

Figure 5. Phytophagous insects found in net trap at Zinnia sp. area: Acraea violae (A), Locusta migratoria (B), Acrida cinerea (C) 


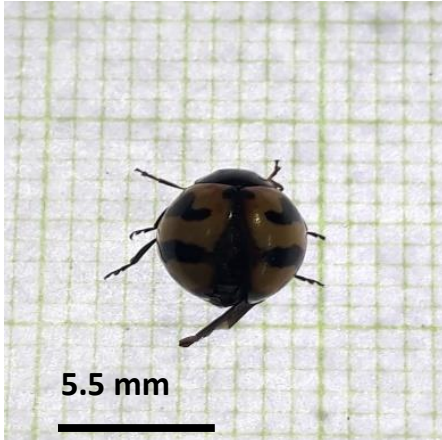

A

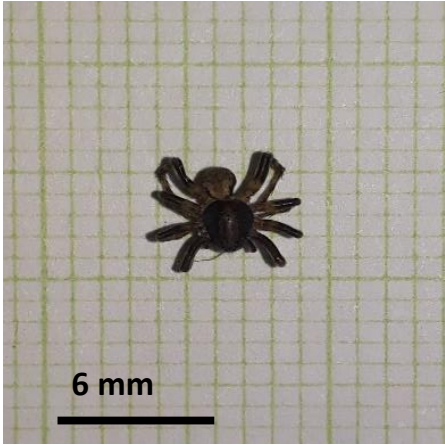

D

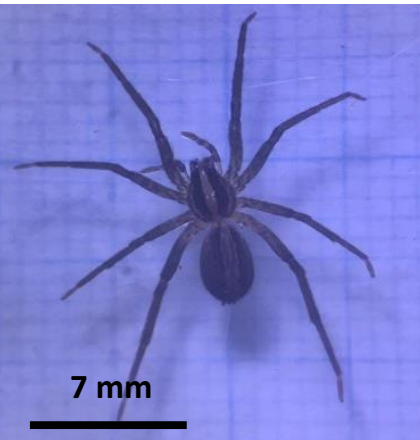

B

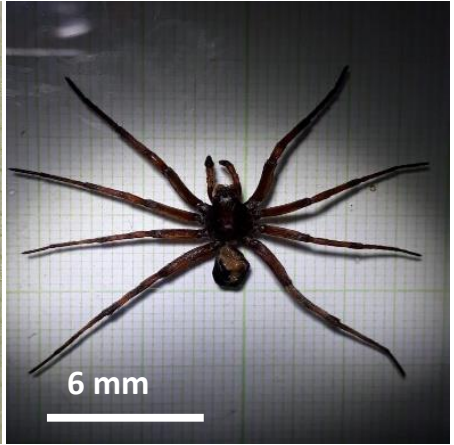

$\mathbf{E}$

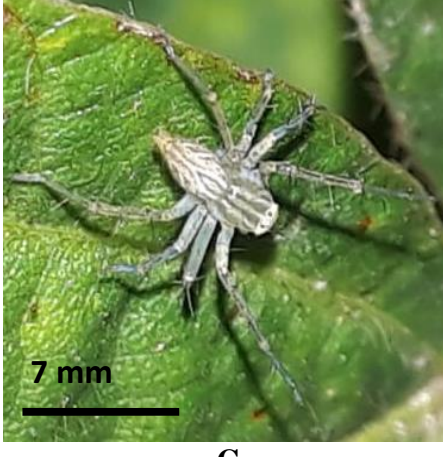

C

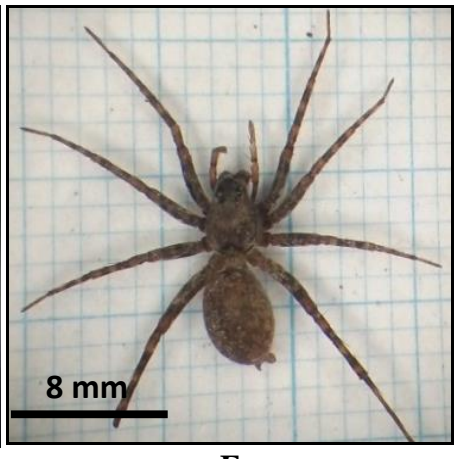

$\mathbf{F}$

Figure 6. Predatory arthropods found in net trap at Zinnia sp. cultivation ara: Cocinella transversalis (A), Pardosa distincta (B), Oxyopes javanus (C), Lycosa pseudomonas, (D), Pardosa sp. (E), Drapetisca socialis (F)

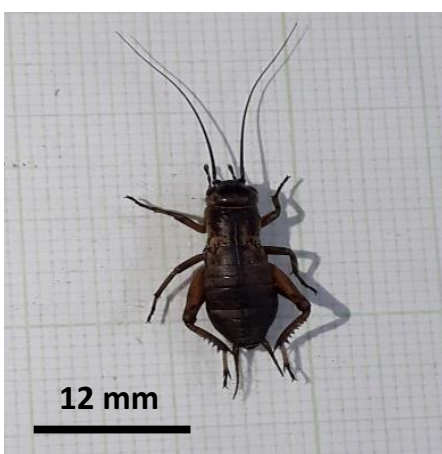

A

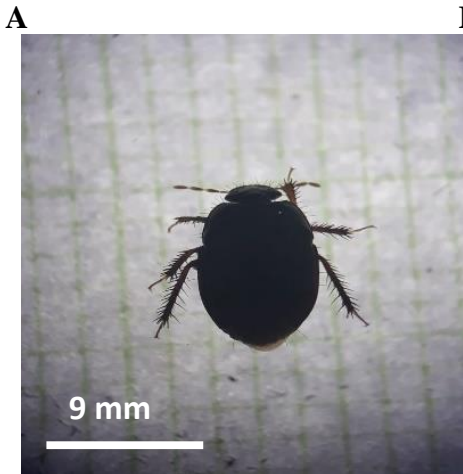

D

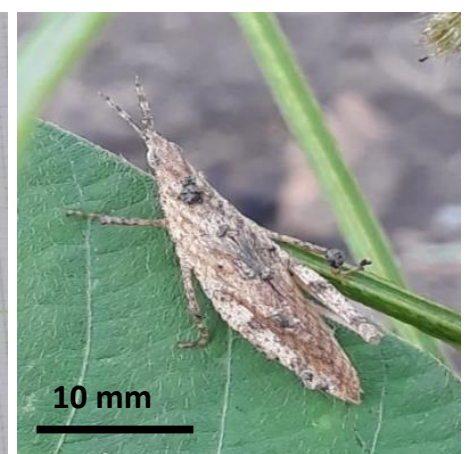

B

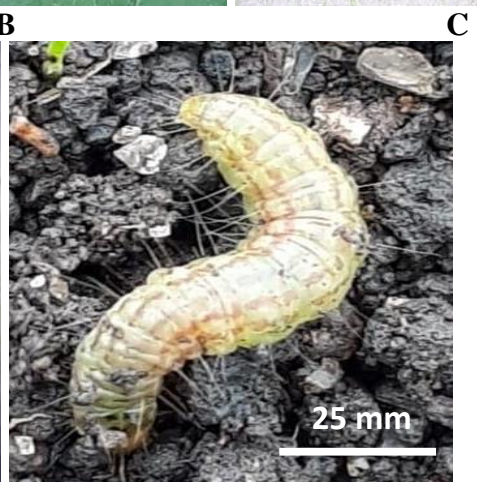

$\mathbf{E}$

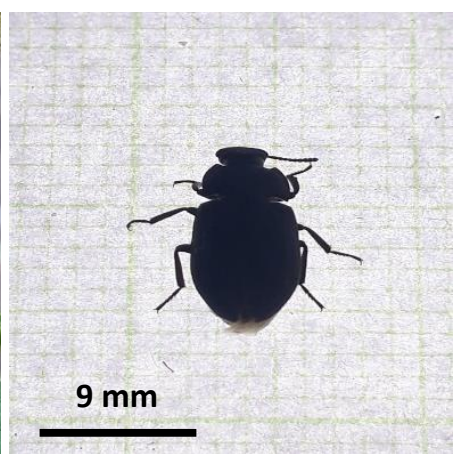

Figure 7. Phytophagous insects found in pit-fall trap at Zinnia sp. area: Gryllus sp. (A), Tetrix subulata (B), Tenebrio molitor (C), Cydnus aterrimus (D), Etiella zinckenella $(\mathrm{E})$

Soil active insects found in the zinnia plant cultivation area found in pitfall traps were 14 species from 8 families, including Gryllidae. Tettigoniidae, Formicidae, Tenebrionidae, Cicindellidae, Cydnidae, Linyphiidae, Pyralidae. Phytophagous insects found were Gryllus sp., Tetrix subulata, Tenebrio molitor, Cydnus aterrimus, and Etiella zinckenella (Figure 7). The most Phytophage insect found was Tetrix subulata of 67 individuals. Predatory arthropods found were insects and spiders, namely Odontoponera denticulata, Solenopsis sp., Lophyra intermedia, Drapestica socialis, Oxyopes javanus, Pardosa distincta, Pardosa sp., and Lycosa pseudomonas (Figure 8). Black ants (Odontoponera denticulata) were as many as 61 collected. 


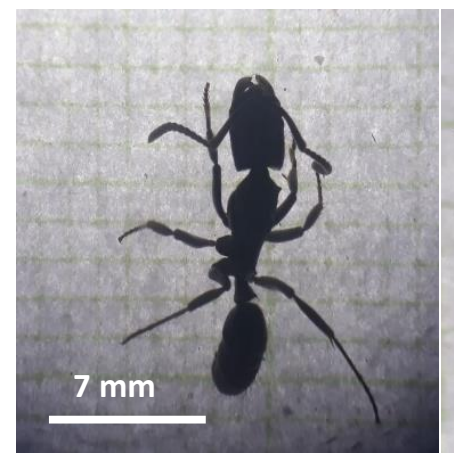

$\mathbf{A}$

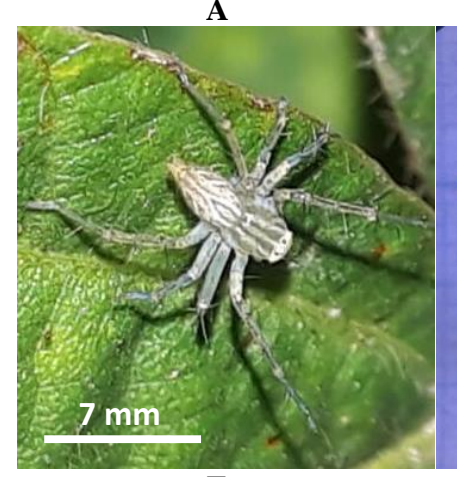

E

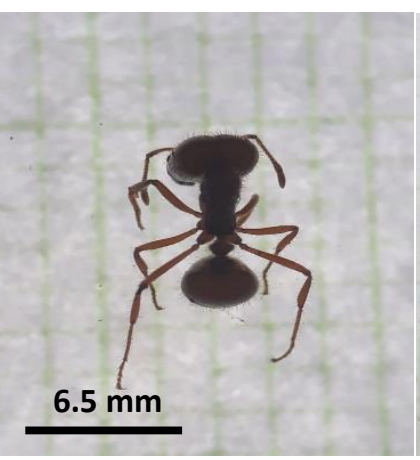

B

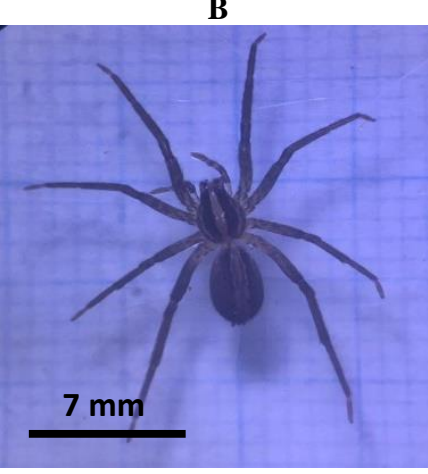

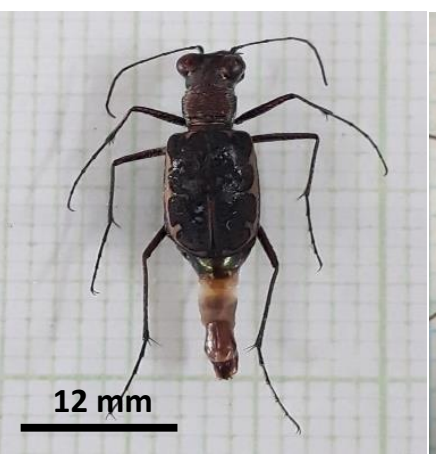

C

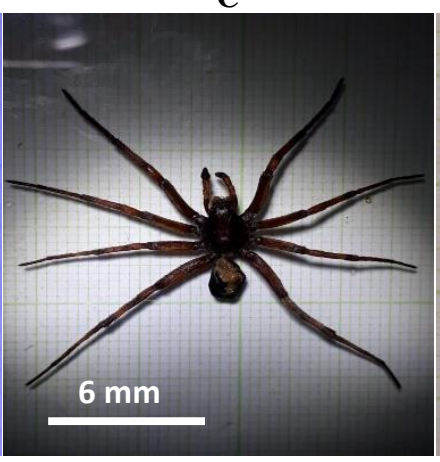

$\mathbf{G}$

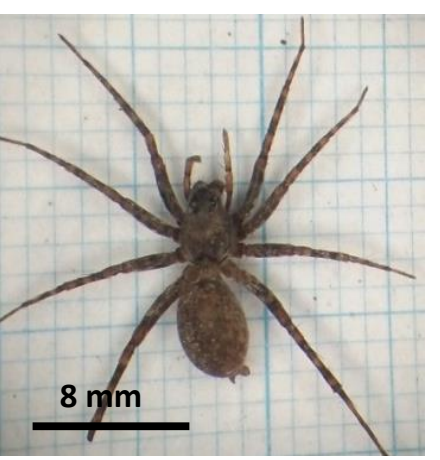

D

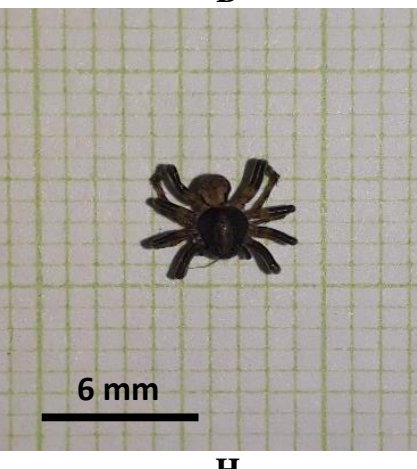

H

Figure 8. Predatory arthropods found in pit-fall trap at Zinnia sp. area: Odontoponera denticulate (A), Solenopsis sp. (B), Lophyra intermedia (C), Drapetisca socialis (D), Oxyopes javanus (E), Pardosa distincta (F). Pardosa sp. (G), Lycosa pseudomonas (H)

On observation, several predatory arthropods and phytophagous insects were found in zinnia but not seen in soybeans (Table 1). The number of predatory arthropods found in zinnia is nine species, while there are only six species in soybean. Among identified entomophagous insects, 4 species found in both plants such as Odontoponera denticulata, Solenopsis sp. Coccinela transversalis, and Lophyra intermedia. On the other hand, 11 species of pest insects were in soybeans and 8 species in zinnia. Mutual species found in both plants were Tetrix subulata, Locusta migratoria, Gryllus sp., Tenebrio molitor, and Cydnus aterrimus.

The total of individual predatory arthropods found in nets and pitfall traps were more numerous in zinnia than in soybean (Table 2). Besides, diversity index and dominance index were higher in zinnia than soybean. However, evenness of predatory arthropods was higher in soybean. On contrary, total number of individual diversity index and evenness of phytophagous insects found in net and pitfall traps were higher in soybeans than zinnia (Table 3). The same species found in soybean and zinnia (Table 1, Tables 4 and 5) were analyzed using chi-square analysis to determine whether there were statistical differences in the number of species. According to chi-square analysis (Tables 6 and 7), the dominancy of predatory arthropods in soybean was higher than zinnia. Among identified species, Locusta migratoria was significantly higher in soybeans than in zinnia (Table 4). Simultaneously, the number of transverse lady beetle (C. transversalis) predators was not significantly different in soybeans and zinnia (Table 5).
Table 1. Comparison of phytophagous insects and predatory arthropods found in soybean and Zinnia

\begin{tabular}{|c|c|c|c|}
\hline Role & Species & Soybean & Zinnia \\
\hline \multirow{10}{*}{$\begin{array}{l}\text { Predatory } \\
\text { arthropods }\end{array}$} & Odontoponera denticulata & $\checkmark$ & $\checkmark$ \\
\hline & Solenopsis sp. & $\checkmark$ & $\checkmark$ \\
\hline & Coccinella transversalis & $\checkmark$ & $\checkmark$ \\
\hline & Micraspis discolor & $\checkmark$ & - \\
\hline & Lophyra intermedia & $\checkmark$ & $\checkmark$ \\
\hline & Drapetisca socialis & - & $\checkmark$ \\
\hline & Oxyopes javanus & - & $\checkmark$ \\
\hline & Pardosa distincta & - & $\checkmark$ \\
\hline & Pardosa sp. & - & $\checkmark$ \\
\hline & Lycosa pseudomonas & - & $\checkmark$ \\
\hline \multirow{14}{*}{$\begin{array}{l}\text { Phytophagous } \\
\text { insects }\end{array}$} & Tetrix subulata & $\checkmark$ & $\checkmark$ \\
\hline & Locusta migratoria & $\checkmark$ & $\checkmark$ \\
\hline & Hypomeces sp. & $\checkmark$ & - \\
\hline & Spodoptera litura & $\checkmark$ & - \\
\hline & Bemisia tabaci & $\checkmark$ & - \\
\hline & Bothrogonia addita & $\checkmark$ & - \\
\hline & Empoasca sp. & $\checkmark$ & - \\
\hline & Penthicodes sp. & $\checkmark$ & - \\
\hline & Gryllus sp. & $\checkmark$ & $\checkmark$ \\
\hline & Tenebrio molitor & $\checkmark$ & $\checkmark$ \\
\hline & Cydnus aterrimus & $\checkmark$ & $\checkmark$ \\
\hline & Acraea violae & - & $\checkmark$ \\
\hline & Acrida cinerea & - & $\checkmark$ \\
\hline & Etiella zinckenella & - & $\checkmark$ \\
\hline
\end{tabular}

Note: $\checkmark$ : present,-: absent 
Table 2. Total of individual, diversity index, domination index, and evenness of predatory arthropods collected in net trap and pitfall trap (individual)

\begin{tabular}{lllcc}
\hline Role & Methods & Community characteristics & $\begin{array}{c}\text { Soybean } \\
\text { (individual) }\end{array}$ & $\begin{array}{c}\text { Zinnia } \\
\text { (individual) }\end{array}$ \\
\hline Predatory arthropods & Net trap & Total of individual & 4.61 & 1.87 \\
& & Diversity index (H') & 1.27 & 1.74 \\
& & Dominance index (D) & 0.55 & 0.25 \\
& & Evenness (E) & 0.79 & 0.97 \\
& Pitfall trap & Total of individual & 5.29 & 8.4 \\
& & Diversity index (H') & 1.01 & 0.5 \\
& & Dominance index (D) & 0.92 & 0.32 \\
\end{tabular}

Table 3. Total of individual, diversity index, domination index, and evenness of phytophagous insects collected in net trap and pitfall trap (individual)

\begin{tabular}{lllcc}
\hline Role & Methods & Community characteristics & $\begin{array}{c}\text { Soybean } \\
\text { (individual) }\end{array}$ & $\begin{array}{c}\text { Zinnia } \\
\text { (individual) }\end{array}$ \\
\hline Phytophagous & Net trap & Total of individual & 11.41 & 6.38 \\
insects & & Diversity index (H') & 2.16 & 1.06 \\
& & Dominance index (D) & 0.23 & 0.47 \\
& Pitfall trap & Tonness (E) & 1.04 & 0.96 \\
& & Dotal of individual & 8.71 & 7.96 \\
& & Diversity index (H') & 3.82 & 1.27 \\
& & Dominance index (D) & 0.32 & 0.35 \\
\end{tabular}

Table 4. The number of phytophagous and entomophagous insects found in soybean and zinnia plantations through the pitfall trap method (individual)

\begin{tabular}{|c|c|c|c|c|}
\hline Order/ Family & & Species & $\begin{array}{c}\text { Soybean } \\
\text { (individual) }\end{array}$ & $\begin{array}{c}\text { Zinnia } \\
\text { (individual) }\end{array}$ \\
\hline \multirow[t]{8}{*}{ Entomophagous Insects } & Hymenoptera/Formicidae & Odontoponera denticulata & 63 & 61 \\
\hline & Hymenoptera/Formicidae & Solenopsis sp. & 44 & 48 \\
\hline & Coleoptera/Cicindelidae & Lophyra intermedia & 20 & 22 \\
\hline & Araneae/Linyphiidae & Drapetisca socialis & 0 & 11 \\
\hline & Araneae/Lycosidae & Oxyopes javanus & 0 & 21 \\
\hline & Araneae/Lycosidae & Pardosa distincta & 0 & 15 \\
\hline & Araneae/Lycosidae & Pardosa sp. & 0 & 4 \\
\hline & Araneae/Lycosidae & Lycosa pseudomonas & 0 & 17 \\
\hline \multirow[t]{5}{*}{ Phytophagous insects } & Orthoptera/Gryllidae & Gryllus sp. & 63 & 48 \\
\hline & Orthoptera/Tettigonidae & Tetrix subulata & 68 & 67 \\
\hline & Coleoptera/Terebrionidae & Tenebrio molitor & 47 & 35 \\
\hline & Hemiptera/Cydnidae & Cydnus aterrimus & 31 & 25 \\
\hline & Lepidoptera/Pyralidae & Etiella zinckenella & 0 & 15 \\
\hline
\end{tabular}

Table 5. The number of phytophagous insects and predatory arthropods found in soybean and zinnia cultivations through the net trap method

\begin{tabular}{|c|c|c|c|c|}
\hline Role & Order/ Family & Species & Soybean & Zinnia \\
\hline \multirow{9}{*}{ Predatory arthropods } & Hymenoptera/Formicidae & Odontoponera denticulata & 7 & 0 \\
\hline & Hymenoptera/Formicidae & Solenopsis sp. & 17 & 0 \\
\hline & Coleoptera/Coccinellidae & Coccinella transversalis & 61 & 40 \\
\hline & Coleoptera/Coccinellidae & Micraspis discolor & 17 & 0 \\
\hline & Araneae/Linyphiidae & Drapetisca socialis & 0 & 22 \\
\hline & Araneae/Lycosidae & Oxyopes javanus & 0 & 13 \\
\hline & Araneae/Lycosidae & Pardosa distincta & 0 & 33 \\
\hline & Araneae/Lycosidae & Pardosa sp. & 0 & 21 \\
\hline & Araneae/Lycosidae & Lycosa pseudomonas & 0 & 28 \\
\hline Phytophagous & Orthoptera/Tettigoniidae & Tetrix subulata & 20 & 0 \\
\hline \multirow{9}{*}{ insects } & Orthoptera/Acrididae & Locusta migratoria & 27 & 13 \\
\hline & Coleoptera/Curcolionidae & Hypomeces sp. & 18 & 0 \\
\hline & Coleoptera/Noctuidae & Spodoptera litura & 64 & 0 \\
\hline & Hemiptera/Aleyrodidae & Bemisia tabacii & 56 & 0 \\
\hline & Hemiptera/Cicadellidae & Bothrogonia addita & 17 & 0 \\
\hline & Hemiptera/Cicadellidae & Empoasca sp. & 45 & 0 \\
\hline & Hemiptera/Cicadidae & Penthicodes sp. & 19 & 0 \\
\hline & Orthoptera/Nymphalidae & Acraea violae & 0 & 24 \\
\hline & Orthoptera/Catantopidae & Acrida cinerea & 0 & 14 \\
\hline
\end{tabular}


Table 6. Phytophagous and entomophagous insects found in net trap of both soybean and zinnia cultivation

\begin{tabular}{lllcccc}
\hline Role & Ordo & Species & Soybean & Zinnia & Chi-square & P-value \\
\hline Phytophage & Orthoptera & Locusta migratoria & 27 & 13 & $4.9^{*}$ & 0.02 \\
Entomophage & Coleoptera & Coccinella transversalis & 61 & 42 & $3.5^{\text {ns }}$ & 0.06 \\
\hline
\end{tabular}

Note: * means the number of insect species that significantly different with chi-square analysis at alpha 0.05

Tabel 7. Entomophagous insects found in pitfall trap of both soybean and zinnia cultivation

\begin{tabular}{lllcccc}
\hline Role & Ordo & Species & Soybean & Zinnia & Chi-square & P-value \\
\hline \multirow{4}{*}{ Entomophagous } & Hymenoptera & Odontoponera denticulata & 63 & 61 & $0.032^{\mathrm{ns}}$ & 0.85 \\
insects & Hymenoptera & Solenopsis sp. & 44 & 47 & $0.009^{\mathrm{ns}}$ & 0.75 \\
& Coleoptera & Lophyra intermedia & 20 & 22 & $0.009^{\mathrm{ns}}$ & 0.75 \\
& Orthoptera & Gryllus sp. & 63 & 48 & $2.02^{\mathrm{ns}}$ & 0.15 \\
& Orthoptera & Tetrix subulata & 66 & 67 & $0.007^{\mathrm{ns}}$ & 0.93 \\
& Coleoptera & Tenebrio molitor & 47 & 36 & $1.45^{\mathrm{ns}}$ & 0.22 \\
& Hemiptera & Cydnus aterrimus & 31 & 25 & $0.64^{\mathrm{ns}}$ & 0.42 \\
\hline
\end{tabular}

Note: ns: not significantly different at alpha 0.05

\section{Discussion}

Soybean cultivation was from November 2019 until January 2020 when rainfall was moderate of 200-300 mm rainfall (BMKG 2019). However, on certain rainy days, the moisture was sufficient for creating a damp and wet environment in the study area. The raised temperature will cause more abundant insect pests that almost all insects will be affected by changes in temperature (Kambrekar et al. 2015). Insect has a different response to changes in seasons and climate (Musolin and Saulich 2012).

Soybean was attacked by enormous species: Orthoptera: Tetrix subulata, Gryllus sp., Locusta migratoria. Coleoptera: Hypomeces sp. Lepidoptera: Spodoptera litura, Hemiptera: Bemisia tabaci, Hemiptera: B. addita, Empoasca sp., Penthicodes sp., C. atterimus, Coleoptera: T. molitor. While predatory arthropods in soybean were six species, including Hymenoptera: $O$. denticulata, Solenopsis sp., Coleoptera: C. transversalis, Micraspis discolor, L. intermedia.

There were eight species of pests found in refugia, including Orthoptera: Gryllus sp, Tetrix subulata, Coleoptera: T. molitor; Hemiptera: $C$. aterrimus, Lepidoptera: $E$. zinckenella, Orthoptera: A. violae, $L$. migratoria, A. cinerea. On the other hand, predatory arthropods found in zinnia cultivation were nine species: Hymenoptera: $O$. denticulata; Solenopsis sp., Coleoptera: L. $\quad$ intermedia, $C$. transversalis, Aranae: Drapetisca socialis, O. javanus, $P$. distincta, Pardosa sp.

Soybean was mostly attacked by $S$. litura, mostly found through the net method, while Tetrix subulata was the most insect pest found in soy and zinnia through the pitfall trap method. S.litura is an economically important polyphagous insect that is widely distributed throughout Asia (Sundar et al. 2018). S. litura generally attacks young leaves and pods when soybeans start flowering. This pest actively attacks plants at night and, hiding behind the ground, leaves in the daytime. T. subulata is the Slender Ground-hopper has a distinct preference for moist habitats near good moss flora. T. subulata is most frequently found on the muddy edges of ponds and streams and in wet meadows (Song 2018). T. subulata is the pygmy grasshopper that has a small $(<15$ $\mathrm{mm}$ total body length, mean dry body mass of $0.07 \mathrm{~g}$ ), diurnal, ground-dwelling and widely distributed insect that inhabits biomes (Karpestam and Forsman 2013).

On the other hand, predatory insects found from pitfall trap both in soybean and zinnia were O.denticulata. In contrast, $C$. transversalis found both in soybeans and zinnia from the net trap method, and predator spiders found only in zinnia (Table 1). O. denticulata is ant predator of other invertebrates, in Indonesia, these ants found are in shrubs, dryland agriculture, and settlements (Latumahina et al. 2015). This species is moderately large with hard-bodied species with large blunt teeth on the sides of the pronotum and a crenulate anterior clypeal margin (General and Alpert 2012). C. transversalis (Thunberg) (Coleoptera: Coccinellidae) is a species of cocci abundant predators in Asia that have a wide range of prey namely soft-bodied insects, especially aphids (Efendi et al. 2018).

There were five species of spiders found only at zinnia cultivation area were $P$. distincta, $O$. javanus, $L$. pseudomonas, Pardosa sp, and D. socialis. The spiders are generalist predators that can eat insect pests from several orders such as grasshoppers, ladybugs, gray-worms, etc. According to Gullan and Cranston (2014), Spiders are predators of polyphagous and potentially control various species of insect pests.

Spiders are influenced by changing environmental conditions and can be used as indicators of habitat quality in forest ecosystems, which are the most abundant groups of terrestrial predators, relatively easily sampled through methods like pitfall trapping (small plastic cups placed in the ground) (Oxbrough and Ziesche 2013). Members of two spider families in particular Thomisidae family (crab spiders) and Oxyopidae family (lynx spiders) often hide among flowers to ambush flower-visiting insects (Wardhaugh 2015). The crab spider can camouflage within the flowers such as crab (Cowles 2018). Moreover, some species can change color to match the flowers they hunt 
(Bradley 2012). Therefore, the flowers can help the spiders to hunt their prey. Predatory arthropods that exist both in zinnia plants and soybeans also had function as predators that feed the phytophagy insects on soybean plants.

Meanwhile, the number of predatory arthropod species was higher than phytophagous insects in zinnia plant. It indicated that planting zinnia flowers in the non-crop area optimized the presence of natural pest control. The vast majority of flower-visiting species and the most important pollinators belong to the four most significant insect orders: beetles (Coleoptera), flies (Diptera), moths, and butterflies (Lepidoptera), and bees, wasps, and ants (Hymenoptera) (Wardhaugh 2015).

The species diversity index is an index that states the community's structure and the stability of the ecosystem. Higher species diversity index means more stable ecosystem. The diversity index $\left(\mathrm{H}^{\prime}\right)$ of predators in the nets method at soybean plants and the refugia cultivation area was 1.27 and 1.74 , respectively. The value was $1<\mathrm{H}^{\prime}<3$ classified as moderate based on the Shannon-Wiener diversity index. While in the pitfall trap method, the diversity index $\left(\mathrm{H}^{\prime}\right)$ of the predator in both soybean and zinnia was 1.01 and 1.82, classified as 'moderate' based on the Shannon-Wiener index. On the other hand, phytophagous insects both in net and pitfall trap method at soybean cultivation were 2.16 and 3.82 , classified as high compared to phytophagous insects found in refugia through net and pitfall trap. The moderate diversity index indicated no dominant insect, while the high diversity index showed the availability of dominant insects. The value of the dominance index showed predators in net and pitfall trap indicated no dominant insect at both soybean and zinnia cultivation area based on the Berger-Parker dominance index. These results were also consistent with evenness index values which no dominant insect species found. Compared to zinnia, the high of diversity phytophagous insect found both in soybean through net and pitfall trap indicated that phytophagous insects mostly attacked soybean than zinnia, meanwhile, the diversity of predatory arthropods (entomophagous insect and spiders) found in soybean and zinnia through net and pitfall trap had the similar categorized index value indicated that the number of predatory insects found canopy and soil habitat was similar between soybean cultivation and zinnia.

Based on the statistical analysis, L. migratoria had a greater number significantly different of insects in soybeans than in refugees (P-value of 0.02). On the other hand, several entomophagous insects $C$. transversalis, $O$. denticulata, Solenopsis sp., $L$. intermedia showed no significant difference in both soybeans and zinnia. The presence of predatory arthropods in refugia and soybean was similar (chi-square at alpha 0.05) indicated that the soybean had a similar role as refugee plants. This condition has happened since soybean also has yellow flowers that can attract the arthropods that act as predatory niches. Yellow attracts insect predators such as Harmonia axyridis (Adedipe and Park 2010). The high proportion of yellow flowers provides accessible nectar, which is suitable to attract and conserve a diversity of generalist predators as well as parasitoids (Hatt et al. 2019). Predators attract and visit bloom flowers, according to Hatt et al. (2017) in mixture flowers planting treatments, Ladybeetles, predator aphids, were more abundant in with very low, intermediate, high functional diversity of flowers.

Many visitors are attracted to bright or contrast flowers (Karban 2015). The presence of flowers provides food for natural enemies evolved to be conspicuous to pollinators ( $\mathrm{Lu}$ et al. 2014). The key attractants of flowers are volatiles, color, architecture and availability of reward (nectar or pollen) (Miller and Rørslett 2011). Conspicuous greenish-yellow tint of fennel's petal is among the most attractive colors for pollinators (Faegri and Van Der Pijl 2013). Skaldina (2020) stated that sweet fennel Foeniculum vulgare that has yellow flowers attracts a diverse assemblage of beneficial insects, and can be recommended as a magnet species. Therefore, the soybean that also has yellow flowers also can play a role as refugia.

In conclusion, the number of pest species in soybean was higher than in zinnia. Meanwhile, predators' existence in soybean less than in zinnia numbered nine species. The number of species in this study was 19 species of insect pests and 15 species of predators. Spiders only exist in zinnia, but entomophagous insects found in soybeans and zinnia flowers were similar. Therefore, it indicates that soybean also can act as a refugee to provide a niche for predatory arthropods.

\section{ACKNOWLEDGEMENTS}

The authors thank the Agro-Technology Center, Faculty of Agriculture, Sriwijaya University, Indonesia. This research was funded through the Sriwijaya University research fund based on contract number 0016.UN9/SK.LP2M.PT/2019 dated June 21, 2019 and SP DIPA-042.02.2.400953/2019.

\section{REFERENCES}

Adedipe F, Park Y. 2010. Visual and olfactory preference of Harmonia axyridis (Coleoptera: Coccinellidae) adults to various companion plants. J Asia Pac Entomol 13 (4): 319-323. DOI: 10.1016/j.aspen.2010.07.004.

Allifah AN, Yanuwiadi B, Gama ZP, Leksono AS. 2013. Refugia sebagai mikrohabitat untuk meningkatkan peran musuh alami di lahan pertanian. Prosiding FMIPA Universitas Pattimura 2: 113-116. [Indonesian]

Anggraini E, Herlinda S, Irsan C, Harun U. 2020. Diversity of predatory arthropods in soybean (Glycine max L.) Refugia. J Agric Sci Technol 4 (2): 101-117. DOI: 10.32530/jaast.v4i2.165.

Barrion A, Litsinger J. 1995. Riceland Spiders of South and Southeast Asia. International Rice Research Institute, Manila.

Berger W, Parker F. 1970. Diversity of planktonic foraminifera in deepsea sediments. Science 168: 1345-1347.

BMKG. 2019. Analisis Hujan Oktober 2019, Prakiraan Hujan Desember 2019, Januari dan Februari 2020 Provinsi Sumatera Selatan: Vol. Nopember. [Indonesian]

Bradley RA. 2012. Common Spiders of North America. University of California Press, California.

Cowles J. 2018. Amazing Arachnids. Princeton University Press, New Jersey.

Efendi S, Yaherwendi Y, Nelly N. 2018. Biologi dan statistik demografi Coccinella transversalis Thunberg (Coleoptera: Coccinellidae), predator Aphis gossypii Glover (Homoptera: Aphididae). Jurnal 
Perlindungan Tanaman Indonesia 22: 91-97. DOI: 10.22146/jpti.28409. [Indonesian]

Faegri K, Van Der Pijl L. 2013. Principles of Pollination Ecology. Elsevier, Nederland.

General DM, Alpert GD. 2012. A synoptic review of the ant genera (Hymenoptera, Formicidae) of the Philippines. Zookeys 200: 1-111. DOI: $10.3897 /$ zookeys.200.2447.

Gill HK, Garg H. 2014. Pesticides: Environmental Impacts and Management Strategies. Pesticides-toxic aspects 8 (2014): 187.

Gullan P, Cranston P. 2014. The Insects: An Outline of Entomology. John Wiley and Sons.

Hasan N, Suryani E, Hendrawan R. 2015. Analysis of soybean production and demand to develop strategic policy of food self-sufficiency: A system dynamics framework. Procedia Comput Sci 72: 605-612. DOI: 10.1016/j.procs.2015.12.169.

Hatt S, Uyttenbroeck R, Lopes T, Mouchon P, Chen J, Piqueray J, Monty, A, Francis F. 2017. Do flower mixtures with high functional diversity enhance aphid predators in wildflower strips?. Eur J Entomol 114: 6676. DOI: 10.14411/eje.2017.010.

Hatt S, Uyttenbroeck R, Lopes T, Mouchon P, Osawa N, Piqueray J, Monty A, Tech GA, Entomology E, Tech A, Agro-bio G. 2019. Identification of flower functional traits affecting abundance of generalist predators in perennial multiple species wildflower strips. Arthropod Plant Interact 13 (1): 127-137. DOI: 10.1007/s11829-0189652-9657.

Kalshoven L, Van der Laan P. 1981. Pests of Crops in Indonesia. Ichtiar Baru-Van Hoeve, Jakarta.

Kambrekar DN, Guledgudda SS, Anand K. 2015. Impact of climate change on insect pests and their natural enemies. Karnataka J Agric Sci 28 (5): 814-816.

Kangas P. 2003. Ecological Engineering: Principles and Practice. CRC Press, Boca Raton, FL.

Karban R. 2015. Plant sensing and communication. University of Chicago Press, Chicago, IL.

Karenina T, Herlinda S, Irsan C, Pujiastuti Y. 2019. Abundance and species diversity of predatory arthropods inhabiting rice of refuge habitats and synthetic insecticide application in freshwater swamps in South Sumatra, Indonesia. Biodiversitas 20 (8): 2375-2387. DOI: $10.13057 /$ biodiv/d200836.

Karpestam E, Forsman A. 2013. Stable isotopes reveal dietary divergence between dispersal phenotypes in Tetrix subulata pygmy grasshoppers (Orthoptera: Tetrigidae). Eur J Entomol 110 (1): 65-70. DOI: 10.14411/eje.2013.008.
Landis D, Wratten S, Gurr G. 2000. Habitat management to conserve natural enemies of arthropod pests in agriculture. Annu Rev Entomol 45 (1):175-201. DOI: 10.1146/annurev.ento.45.1.175.

Latumahina F, Musyafa, Sumardi, Putra NS. 2015. Respon semut terhadap kerusakan antropogenik dalam hutan lindung Sirimau, Ambon. Manusia dan Lingkungan 22 (2): 169-178. [Indonesian]

Lu Z, Zhu P, Gurr GM, Zheng X, Read DMY, Heong K, Yang Y, Xu H. 2014. Mechanisms for flowering plants to benefit arthropod natural enemies of insect pests: Prospects for enhanced use in agriculture. Insect Sci 21 (1): 1-12. DOI: 10.1111/1744-7917.12000.

Magurran A. 1988. Ecological Diversity and Its Measurement. Princeton University Press, New Jersey.

Miller Rãsjo, Rørslett B. 2011. Optics \& laser technology plants and colour: Flowers and pollination. Opt Laser Technol 43 (2): 282-294. DOI: 10.1016/j.optlastec.2008.12.018.

Musolin DL, Saulich AK. 2012. Responses of insects to the current climate changes: From physiology and behavior to range shifts. Entomol Rev 92: 715-740. DOI: 10.1134/S0013873812070019.

Oxbrough A, Ziesche T. 2013. Spiders in forest ecosystems. In: Kraus D, Krumm F (eds) Integrative Approaches as an Opportunity for the Conservation of Forest Biodiversity. (In Focus: Managing Forest in Europe). European Forest Institute, Sarjanr, Finland.

Prokopy RJ. 2003. Two decades of bottom-up, ecologically based pest management in a small commercial apple orchard in Massachusetts. Agric Ecosyst Environ 94: 299-309. DOI: 10.1016/S0167-8809 (02)00036-1.

Skaldina O. 2020. Insects associated with sweet fennel: Beneficial visitors attracted by a generalist plant. Arthropod Plant Interact 14 (3): 399407. DOI: 10.1007/s11829-020-09752-x.

Song H. 2018. Biodiversity of Orthoptera and Phylogeny. II (Sharov 1968). John Wiley \& Sons, New York.

Sundar B, Rashmi V, Sumith HK, Sandhya S. 2018. Study the incidence and period of activity of Spodoptera litura on soybean. J Entomol Zool Stud 6 (5): 331-333.

Wäckers F, Van Rijn P. 2012. Pick and Mix: Selecting Flowering Plants to Meet the Requirements of Target Biological Control Insects. John Wiley \& Sons, New York. DOI: 10.1002/9781118231838.ch9.

Wardhaugh CW. 2015. How many species of arthropods visit flowers?. Arthropod Plant Interact 9: 547-565 DOI: 10.1007/s11829-015-93984. 